\title{
'Killing' Her Journal with Delayed Paratext? Mary Shelley's JoURnal INTERTITLES AND OTHER Distinctive FeATURES
}

\begin{abstract}
One of the most fundamental, although unwritten, rules of diarising is that a diary should not be fiddled with after "the clock strikes midnight", as Philippe Lejeune puts it. A diarist's choice to enter paratext, particularly in the form of intertitles, into his/her self writing, seems to suggest a need for tighter structural controls over the text but also, to use words of Lejeune, it "kills" a journal through the violation of the said rule. All in all, journal intertitles and other forms of journal paratext are not very common, particularly in nineteenth-century women's self writing. If they can at all be found in a diary, what form do they assume? What function do they serve? What effects do they produce? I look at these issues in Mary Shelley's 1814-1844 Journal Books and ponder Lejeune's dictum that rereading and its consequence, i.e. rewriting, can kill a diary.
\end{abstract}

Keywords

English Romanticism; Mary Shelley; women's diaries; paratext; intertitles

When the clock strikes midnight, everything must remain just as it is. The diary's value lies in its being the trace of a moment. If I begin fixing things the next day, I do not add value to my diary: I kill it. As with watercolors, you cannot retouch it later. As soon as you become aware of these constraints, you find them exhilarating.

(Lejeune 2009: 182)

Diarists' rereading and/or rewriting practices are claimed to affect journal truthfulness, sincerity and spontaneity - however elusive these might appear. ${ }^{1}$ Yet it 
is a fact that the majority of "diarists are rereaders" (Blodgett 1988: 74), and that many acts of rereading inevitably slip into acts of revising and rewriting. Diary truthfulness and authenticity are irrevocably compromised if an entry is subject to revision after the recorded day is over: "when the clock strikes midnight", as Lejeune puts it in the compendium of his thoughts On Diary (2009: 182). Revision in a post factum manner "kills" a diary, Lejeune argues passionately (2009: 182), formulating what appears to him a fundamental generic requirement: the once-only nature of any single diaristic act. This does, however, stand somewhat against his view of the diary as a tangible artefact, in which case evidence of revision should rather be taken as a particular diary's distinguishing feature and residue of the diarist's individuated practice - proof of approach to diarising. Diary editing by third parties poses even bigger problems, first remarked on by Arthur Ponsonby who claimed that "no editor can be trusted not to spoil a diary" (1923: 5). "Punctuation marks where there were none or inconsistent capital letters regularized all alter the record of the diarist. Even spaces on a page can communicate, but few editors of a diary can afford to leave them", claims Margo Culley (1985: 16), approximating Lejeune's understanding of the diary as a material relic of a certain life practice (2009) rather than a polished and finished written product. But, whatever its criticisms, diary editing remains a fact.

The Lejeunean ideal, i.e. the "honest" (i.e. un-premeditated, un-reread and un-revised) diary displays several features, such as discontinuity (but leaves an option to be organised into a series and turned into continuity), lacunae or gaps, allusions resulting from the fact that diary entries operate as mnemonic signs, redundancies and repetitions, and last but not least - non-narrativity (in the sense that while individual entries narrate some events, the overall structure does not normally presuppose a beginning, a development and a conclusion, Lejeune 2009: 170-179). Technically speaking, basic requirements of narrativity are met when a diary has a beginning and an end. The beginning usually comes with the diarist's decision to start diarising and, more often than not, carries a statement of diaristic intention (Lejeune calls this the "birth certificate of writing", 2009: 170). However, journals tend to present in medias res beginnings, and on principle rarely feature definite closures or epilogues. Typically, the ending marks another decision, action or circumstances independent of the diarist. Lejeune locates possible conclusions of a diary at any point when the diarist records no more material (due to the diarist's loss of interest, untoward circumstances, death, etc.), or - in more material terms - when the diarist has no more paper on which to write. Whichever the case, the closure is significant in providing the contact zone between the text and its afterlife (Lejeune 2001; 2009). This links to the issue of diary readers/addressees, who, among several possibilities, may include the diary narrator's future selves (Rak 2009: 24). It has been suggested that the four types of journal readers include specified readers close to the writer, future anonymous readers, the diarist him/herself, and the diary personified as a friend or confidant(e) (Czermińska 1977: 113-116): hence the frequently mocked invocation of "Dear Diary". 
The journal genre is subject to a strictly mechanical order, expressed through dating, and its inseparable quality is the option to begin and to end at almost any point. Margo Culley tells us that some "diaries do have distinct shapes, [which] derive from their existence in time passing. Some are shaped by external events in the diarist's life, which, even from the writer's point of view, have a beginning, middle and end. Courtship diaries ending with a marriage and travel diaries ending with the arrival at a destination are examples of such texts" (1985: 19). But the diarist's choice to enter paratext, particularly in the form of intertitles, into his/her self writing, seems to suggest a need for tighter structural control over the text. This might explain why diary intertitles and other forms of diary paratext are not very common, particularly in nineteenth-century women's self writing, which on the whole allows little, if any, space for formal experimentation. If paratext can at all be found in a diary, what form does it assume? What function does it serve? What effects does it produce? Let us look at these issues in Mary Shelley's 1814-1844 five Journal Books, which - in accordance with modern editorial practice - will be viewed as one lifelong life-writing work, split into several volumes due to material necessity (i.e. running out of paper) and punctuated with delayed paratext by the diarist herself.

In Mary Shelley's diaristic metadiscourse, although not contained in the diary entries themselves and thus belonging to the category which Susan Lanser has labelled extrafiction (1981: 8; 124-125) and Gérard Genette - paratext ("the paratext is what enables a text to become a book and to be offered as such to its readers and, more generally, to the public" 1997: 1-2; cf. Genette 1997: 294), of special importance are the intertitles bestowed by the diarist on her journal books (the numbering of the notebooks, however, comes from Shelley's editors). When studying paratext, Genette (1997: 4) recommends examining "its location (the question where?); the date of its appearance and, if need be, its disappearance (when?); its mode of existence, verbal or other (how?); the characteristics of its situation of communication - its sender and addressee (from whom? to whom?); and the functions that its message aims to fulfil (to do what?)". These questions, with the exception of when (impossible to determine in the case at issue), will be looked into in this essay.

A fundamental assumption behind journal keeping is that of privacy which has traditionally been thought to manifest itself through a conspicuous absence of addressees and/or readers (Ponsonby 1923; Spalding 1949; Jackson 2010; et al.). This ought to naturally translate into absence of paratext, paratext being needed when the presence of addressees and/or readers is predicted or assumed. Still, it has been claimed, journals have the capacity to be "addressed, but rarely at the outset or systematically" (Lejeune 2009, 100), and "intimate paratexts" are not impossible to find in diaries (Genette 1997: 387). But what do we make of a diarist who - as Mary Shelley does - imposes intertitles on some sections of her text? And, in consequence, when faced with such practice, to what extent are diary readers "voyeurs when [they] read the diaries of others" (Rak 2009: 20)? Are Shelley's intertitles meant to aid a wider audience? 
In her lifetime, Mary Shelley (née Godwin) produced five journal notebooks. ${ }^{2}$ In Mary's own handwriting, the very first was originally entitled "Shelley and Mary's journal book" (5); ${ }^{3}$ the second one bears the title of "Journal $1816 /$ Begun July 21 - 1816 / Ended with my happiness June 7th 1819" (112); another one - "Journal Book [III] / Begun August - 1819 -" (293); the next one is "The Journal of Sorrow - / Begun 1822 / But for my Child it could not / End too soon" (428); the final "Journal [Book V]" is unintertitled. The surviving original intertitles of Mary Shelley's diaries can hardly be labelled synoptic: ${ }^{4}$ their function is to express either the diarist's emotional states at onset or completion of a particular book, testifying to her attempt to organise and attach identificatory labels to certain stages in her diaristic output from a belated perspective.

Significantly, Mary Shelley's journals display varying stylistic characteristics, depending on the respective stages of her diaristic practice. The early section of the pre-1822 Shelley journal is certainly notable for its collaborative writing. It covers the period from July 1814 (Mary's elopement with Percy to the Continent) to the year 1816, the end of which (30 December) brings their wedding, made possible by the suicide of Percy's first wife earlier in December 1816. In her Journal Book I (summer 1814 - May 1815), Mary's first entry in the journal originally started by Percy Bysshe Shelley (on July 28, 1814), is dated Thursday [August] 11,1814 , a fortnight after their elopement the home of her father, William Godwin. Shelley's early journal is the joint work of Mary and Percy Shelley: they composed some of the entries together, or entered their records in an alternating manner. At the outset, the 1814 diary is a travel journal, recording the continental tour which extends until mid-September 1814, when the penniless lovers return to London. In this section, roughly half of the journal is written by Percy, who is the one to initiate this shared project. In the remaining part of the year 1814, and until the end of the year 1816, entries by Percy become less and less frequent, to gradually disappear from mid- 1819 onwards. The last entry by the poet is part of the entry dated 16 August, 1820, which reads enigmatically: "Do - Finished" (329). Afterwards, the journal becomes Mary's exclusively. Naturally, problems related to the identity of Mary Godwin's narrating "I" emerge in the early stages of her diary, as opposed to the homogeneity of her later post-1822 journal.

In August 1814, in a mundane, reporter-like style, and with her idiosyncratic spelling, Mary narrates part of the trip, their asking the way at a cottage, finding an auberge, eating "milk and sour bread," and observes that locals are not particularly fond of hygiene (12), as was quite common for contemporary travellers to remark (Sweet 2010). She continues in a similar vein for the next two entries, immortalising the rats which pester her stepsister in her sleep, and "the excessive dirt of our habitation" (13), again in keeping with travel journal conventions of her day. Percy Bysshe Shelley takes over once again on the following day and breaks into raptures over a landscape: "From the summit of one of the hills, we see the whole expanse of the valley, filled with a white undulating mist over which the piny hills $\mathrm{p}[\mathrm{i}] \mathrm{erced}$ like islands. The sun had just risen, $\&$ a ray of the red light lay on the waves of this fluctuating vapour..." (15). And so on, and so 
forth, alternating are factual records from Mary Godwin and poetic utterances from Percy. Not once does she acknowledge any diaristic intention. Neither does Percy Bysshe Shelley. It is in all these senses that Book I is truly "Shelley and Mary's journal book," as the intertitle claims: first, his, and only then - hers. Its production is apparently unpremeditated, spontaneous, and altogether unplanned.

In the process of becoming Mary's rather than Shelley's, "Shelley and Mary's journal book" continues, far from personal, always ready for her partner's inspection, and ends with entries which mostly document the diarist's health issues, reading and walking activities, relying on the use of initials to denote the major characters of the journal. The very last sentence in Book I reads: "I begin a new journal with our regeneration" (79): a blatant statement of diaristic intention, but positioned unconventionally - at the end of a complete journal book rather than at the beginning of a new, blank one. The diarist will not even hint that the said "regeneration" refers to a period of time during which, as she puts it earlier without any apparent emotion, "Clary goes" (78). The "regeneration" entry is followed by eight blank pages, and then - by three pages of household accounts, prescriptions, the couple's private pet names, the name of Claire Clairmont copied a couple of times, a doodle, and a final complaint written in Mary Shelley's hand: "Here are we three persons always going about, \& never getting anything. Good God, how wretched!!!!!” (81). This Book ends on May 13, 1815. This is when the two diarists' shared project practically ends, and afterwards will be continued by Mary exclusively.

Mary Shelley's diaristic concept and practice, as seen in her first journal book, both seem rather conventional at first, the initial purpose and design being to document the diarist's elopement to the Continent with its paradoxically unromantic atmosphere (given the presence of her stepsister Claire Clairmont, first as a chaperone and then as a permanent member of the household). Soon after the party's return to England, the diary becomes so secretive that the reader puzzles over the aim of keeping it in the first place: it becomes reduced to mere listings of books read, walks taken or visitors, not infrequently denied full identify and denoted simply with their initials. Even when concerned with major family events - pregnancies, or child births and deaths - the entries hardly make up a family chronicle or baby book because, even if any major event is mentioned in passing, the journal immediately reverts to impersonal records of everyday routines. By embarking on the diary project shared with Percy Bysshe Shelley from the 1814 elopement onwards, Mary Shelley early compromises the privacy of her journals. Aware that they will be perused and jotted in by the poet, she seems wary of communicating her personal reflections without resorting to figurative language.

Shelley's Journal Book II ("Journal 1816 / Begun July 21 - 1816 / Ended with my happiness June 7th 1819", covering the period from July 21, 1816 to June 7, 1819) begins impersonally - with doodles, accounts and reading lists. If there was any private jubilation due to Claire's leaving, it seems to have been gone by now (Feldman and Scott-Kilvert 1995: 103). Is any diaristic intention formulated in this book? If it is, it is not placed at the beginning and is not in the least 
conspicuous: instead, the September 24, 1818 entry, which documents the death of the diarist's daughter, Clara Everina, begins with the statement that " $[t]$ his is the Journal book of misfortunes -" (226). Thus an informal title is bestowed on the part of the journal which the diarist claims "[e]nded with my happiness June 7th 1819" (112). The June 7th entry itself (the date of Shelley's son William's death) is missing, putting an end not only to a section of her journal manuscript, but primarily to any light-hearted and carefree quality that the journal once displayed, even if occasionally. ${ }^{5}$ No clear-cut ending is to be noted, either: Book II ends with reading lists, household accounts, and the like. Feigned impersonality acts as a shield against personal tragedy and resulting trauma. The diary's happiness disappears once and for all.

Although the secrecy of Mary Shelley's journal can appear puzzling or even disconcerting, it is to be accounted for within her overall design: aware that she was a compiler of data for a future biography of Percy Bysshe Shelley, she was at the same time "acutely aware of the perils of indiscretion, and must have very early realized that no written document could ever be considered entirely private" (Feldman and Scott-Kilvert 1995: $\mathrm{xv}-\mathrm{Xvi}$ ). Representative of this growing awareness is perhaps the tendency, observable in Shelley's first couple of diarised years, towards shifting from narrative travel journal entries to those that gradually abandon their informative quality and become increasingly laconic. As this happens, Shelley's metadiscourse intensifies to reflect her practice: it comes to epitomize a yearning for some sort of order to be imposed onto an otherwise irregular existence, deficient in structure, certainty and stability.

Shelley's Journal Book III ("Begun August - 1819 -") covers the period from August 4, 1819 to July 8, 1822, the date of Percy Bysshe Shelley's premature and sudden death. The opening entry of Book III coincides with a celebration of Percy's birthday, but includes neither an intertitle nor a statement of diaristic intention as such. The diarist writes:

I begin my journal on Shelley's birthday - We have lived now five years together \& if all the events of the five years were blotted out I might be happy - but to have won $\&$ then cruelly have lost the associations of four years is not an accident that to which the human mind can bend to without much suffering

Since I left Rome I have read several books of Livy - Antenor - Clarissa Harlowe - The Spectator - a few novels $-\&$ am now reading the Bible \& Lucan's Pharsalia - \& Dante

S has read is today twenty seven years of age - (293-294).

Reflective as it is, this entry of August 4, 1819 resembles a recapitulation rather than an opening. It signals a turn in Shelley's diaristic practice: it is one of the few heralds of the movement away from the hitherto practised brevity and towards less controlled, more emotional utterance. Journal Book III breaks off on the day of Percy's death, only to be continued with the diarist's copying of Edward Trel- 
awny's extensive "Obsequies" under the date of August 12, 1822, as if she was incapable of producing any utterance of her own. Just as no intention is stated, no intertitle is to be found in this journal book, either. Instead, the opening page of Book III bears an allographic (i.e. written by an author other than the life writer) epigraph in Mary Shelley's handwriting. ${ }^{6}$ It comes from her husband's "Sonnet 31", dated November 5, 1817. The epigraph reads:

That time is gone for ever - child Those hours are frozen forever We look on the past, \& stare aghast On the ghosts with aspects strange \& wild Of the hopes whom thou \& I beguiled To death in life's dark river.

The waves we gazed on then rolled by

Their stream is unreturning

We two yet stand, in a lonely land, Like tombs $M$ to mark the memory Of joys $\&$ griefs that fade $\&$ flee In the light of lifes dim morning (293).

As is the case with the already discussed intertitles, there is no knowing when i.e. how long after she completed the composition of her entries into any of the journal books - Mary Shelley added the poem to her journal book. Feldman and Scott-Kilvert suggest that she may have been quoting it from memory, given the discrepancies between this version and the original P. B. Shelley manuscript (1995: 293). On a personal level, the verses are pertinent not only to the diarist's recent losses, but they also uncannily connect to the direst tragedy to occur within the time frame of this journal book, i.e. they fulfil the fundamental paratextual function of "commenting on the text" and, presumably, anticipating it (Genette 1997: 157). Although Genette observes that the Romantic period saw a profusion of epigraphs (1997: 160), this fact does not seem to be of much significance for our understanding of this particular case. In the nineteenth century, epigraphs were commonly used to help subsume the new genre of the novel into culture by demonstrating the links it had with broader cultural tradition (Genette 1997: 160). But the allographic epigraph chosen by Mary Shelley is not accompanied by any attribution; on the other hand, who else would she be expected to quote in the first place but her husband and intellectual companion, even if her reading lists were extensive enough to accommodate a plethora of other authors? A poem by P. B. Shelley seems a most natural choice. Although "the customs of presentation of the epigraph are highly variable", Genette tells us (1997: 152), "[i]t seems, however, that the most common custom is to name the author without giving a specific reference - unless the identity of the epigraphed goes without saying". More importantly, where there is an epigrapher, there is an epigraphee (Genette 
1997: 154-155), and that "[d]etermining the epigrapher more or less determines the epigraphee - the addressee of the epigraph. More or less: when the epigrapher is the author of the book, it goes without saying that for him the epigraphee is the potential reader and, in practice, every real reader" (Genette 1997: 155). Hence the very presence of the epigraph prompts exactly the same questions as the intertitles do: who is the manuscript meant for? It would appear that, as is the case with Mary Shelley's intertitles that seem to cater mainly for the diarist's own purposes, the epigraphee is again the diarist herself. Even if it is assumed that Percy still browses through Mary's diary (there is no sign of him as co-diarist, unlike in Book I), it is in this very Book that this activity of his will irrevocably be terminated by his unexpected death (a common diary closure, according to Lejeune 2009). Mary Shelley will not dare express anything truly private until after Percy's death, which in a sense liberates her, although for obvious reasons the metadiscourse which refers to this process presents it painful. It will in due course induce her to search for more intimate as well as more figurative ways of exploring the self. The function of personal expression takes over in mid-1822, the absence of the diarist's reader, unsurprisingly, altering her perspective.

Following her 1822 bereavement, Shelley's concept of her journal changes radically - and so does her practice. Metadiscourse increases in intimacy, the less and less regular entries grow considerably longer, and effusions become completely personal (even then, not entirely devoid of lacunae). The result is a sort of a journal intime, at times enriched with characteristics of a self-portrait as the diarising "I" ruminates on her innermost doubts and anxieties or justifies her choices in life (this is the ideological function of the narrator, according to Genette 1980: 257). Detachment from the external reality progresses but it is not complete: one of Shelley's final journal notebooks ends with a list of the diarist's acquaintances, a pure memory-aiding, mechanical operation.

When Mary Shelley undertakes to resume her writing after the meaningful silence following her husband's tragic death, she does so by beginning from the back to the front of her journal book, literally turning over a new leaf and implying a turning upside down. As already indicated, in an act of refusal to cope with her own feelings under the circumstances, she copies almost one hundred pages of the journal by Edward Williams. Edward Williams was the friend with whom Percy Bysshe Shelley set out for his last voyage, and who perished together with him. Williams' diary covers the period between late October 1821 and 4 July, 1822 , and since the notebook itself was not destroyed by the water, it was handed to Mary Shelley who, in preparation perhaps for her projected compilation of a P. B. Shelley biography (Feldman and Scott-Kilvert 1995: 417), transcribed a large part of it. She then follows with a several-page-long transcription of a narrative entitled "Trelawny's account of the Obsequies of Shelley and Williams" (419-425), thus creating the most curious lacuna of her journals: a prolonged silence, followed by exhaustive narrative accounts - but not her own. Unable to relate the events herself in the 1822 journal, she soon compensates for this with a vengeance in her private correspondence (cf. the August 1822 letters to Maria 
Gisborne and Edward Dawkins, Secretary to the Legation in Tuscany, Shelley 1995a: 98-104). The transcription of both of the said texts constitutes a climax in the impersonality of Mary Shelley's journal: no comments of her own are offered and no further intertitles are inserted. This, at the same time, proves to be the final stage at which her impersonality rules. Afterwards, the journal will never display that quality again. In the meantime, a startling transformation has occurred: considering the external circumstances of the journal's composition, the lack of a reader becomes a striking absence. This eliminates the need for the diarist to edit her text, organise it, or create a self which she is ready to present to the wider world. As Mary Shelley's journal begins to gravitate towards the journal intime with its increasingly confessional mode, any observable discrepancy between the narrating "I" and the narrated "I" ceases to exist (after Smith and Watson 2001).

The first impression on reading Mary Shelley's post-1822 journal is that the entries become visibly longer, and their content shifts to retrospective and confessional. The latter is what makes the text approximate a journal intime in every sense of the term, recording the diarist's private thoughts and reflections. This new use of the journal is signalled occasionally (for example "I try to examine myself", 557) and it may be claimed that this results from the narrating "I" being no longer intimidated or restrained by her reader, the poet whom she valued aesthetically higher than herself, despite the fact that she was at the time the more famous of the two Shelleys.

Unlike the first three books, in the post-1822 Book IV ("The Journal of Sorrow - / Begun 1822 / But for my Child it could not / End too soon", spanning October 2, 1822 - December 8, 1825), the very first entry written by Mary Shelley after her husband's death, on October 2, 1822, contains a long yet rambling account of her diaristic intention. The entry harks back to the previous journal, which stopped "[o]n the Eighth of July ..., the fatal 8th" (429). The fact that the date remains a blank is now taken by the diarist as "a monument to shew that all ended then" (429). This is followed by the question: "And I begin [diarising/ new life?] again?", to which the diarist replies: "oh. never!" (429). This negative reply is contradicted in the following sentence with a list of several reasons why resuming her journal would be advisable, with the diarist complaining about her current friendlessness and loneliness. Having stated dramatically that "[t]he stars may behold my tears, \& the winds drink my sighs - but my thoughts are a sealed treasure which I can confide to none" (429), the diarist proceeds to ask: "White paper - wilt thou be my confident? I will trust thee fully, for none shall see what I write. But can I express all I feel? Have I the talent to give words to thoughts \& feelings that as a tempest hurry me along? -" (429)

Although relying mostly on rhetorical questions, this statement of diaristic intention, complete with the need for a recipient of the writer's confidences (expressed at the beginning of the first October 1822 entry) does not seem to appease or satisfy the writer. In the same entry, she concludes: "Well then, I am now reduced to these white pages which I am to blot with dark imagery" (430). The function of the diary, now, is not to be associated with pleasure of any kind, but 
instead it will be Mary Shelley's last resort to transfer the experienced despair onto a tangible, white sheet of paper - a tabula rasa. It is indeed remarkable that the diarist imposed no intertitle on that section of her life writing.

Why did she make this particular choice - why did she opt for the absence rather than presence of an intertitle? Is it because at last she will be able to express what and how she pleases, without having to be secretive and thus in need of meaningful journal book titles? The post- 1822 journal will become dominated by dark moods and death wishes, resulting from a sense of evil and personal inadequacy. The first entry (October 2, 1822) ends with the following: "Well, good night, Good Book, Book dedicated to Silence - Night \& Shelley. Goodnight, a tear consecrates your use - ... until I open you again" (432). This sentence qualifies the journal notebook as "good", one of the few positive statements to be made in it. Importantly, its sanctity is soon articulated openly for the first time, and this sanctum-like function is to be continued in entries centred on the holiness and otherworldliness of the diarist's late husband. Yet the final clause establishes the position of the diarist as the one in control of her Book: it is she who decides when to open the journal and use it. Journal Book IV ends with Mary Shelley's poems "The Choice", 7 "On Reading Wordsworth's Lines on Peel Castle" and "To Jane" (490-495). Out of these, the first is the most personal as it delineates the widow's remorse at not having shown more warmth to her spouse in his lifetime. No distinct closure is provided, and the next is the non-intertitled Journal Book V. It comprises entries dated September 5, 1826 to October 2, 1844. Once again, no diaristic intention is stated at the outset, the diarist barely noting that what spurs her to put pen to paper is the arrival of a portrait of her late husband, painted back in 1819 , which now strikes her with its unearthly quality (496). The closing entry (October 2, 1844) brings a single quotation from Edmund Burke, recommending "a habit of giving" (573). This is as cryptic as ever, and without the help from Shelley's biographers, the reader would hardly know that the advocated generosity was brought to the diarist's mind in connection with her son Percy's coming into his family inheritance and settling his late father's financial obligations (Feldman and Scott-Kilvert 1995: 573).

The above evidence clearly shows that although not all Shelley's journal books are given authorial intertitles, those intertitles that there are were clearly meant to organise the content of the journal. Who for? Either for both the reader of her journal - Percy (as in Book I) and the diarist, or for the diarist herself exclusively (as in Books III and $I V$ ). Notwithstanding the above, it has to be remembered that generic journal characteristics, such as dating or serial quality, continue to be present in Mary Shelley's life writing at all stages. Yet the diarist's tendency to relate to the external world is increasingly pushed to the background. Partly replaced with the private matter of the diarist's emotions, partly with the diarist's personal ruminations on her idealised past and anticipated dark future, including a desire for annihilation, the journal dispenses with whatever narrative quality it once had, and comes to rely increasingly on intimate confession, where little need exists to organise the content (hence the non-intertitled Book V). 
As has been shown, the intertitles illustrate a rare case of a life writer complementing her personal documents with extra-textual elements. They also serve to accentuate the journal's transitions from impersonality to personality, from readership to no readership, and from a strong bond with the reality to a link that is, to say the least, tentative. Although journal beginnings tend to be rather explicit when it comes to expressing diaristic intentions or organising diaristic material and that "it is rare to begin [a journal] without saying so" (Lejeune 2009: 187), it would seem that Mary Shelley replaces statements of diaristic intention with intertitles in a way which renders explicit declarations of diaristic intent redundant.

It is not known whether Mary Shelley intended her life writing for publication. Yet, given the amount of self-censorship and self-imposed secrecy which she consistently exercised in the diaries penned over the years spent living with Percy Bysshe Shelley and after, she must have realised that one day her private jottings may become public. As such, they would be of interest to a wider audience who would mine them for intimate details of the famous poet's daily life. In that, she was not mistaken: only seven years after her death, in 1858, a selection of her journal entries was published in T. J. Hogg's Life of Shelley; others appeared in 1859 as Lady Shelley's Shelley Memorials; only to be followed in 1882 with Lady Shelley's Shelley and Mary.

Which is not to say that the whole of her diary writing appears totally controlled: reread and revised. Consider, for instance the lacuna between 25 October and 4 November, 1820, thus is accounted for by the diarist: "Having had an inflamation [sic] of my eyes my journal \& every thing else has been neglected -" (338). In this faulty grammar structure and spelling of this passage of metadiscourse, I would see evidence of the spontaneity with which it was put down. It simply points to the fact that the diarist omits to take the time to fiddle with her previous entries.

In contrast, there exists a record of only one passage (19 March, 1823) which explicitly testifies to the diarist's rereading of what she has written before. It reads: "Such are my quiet reveries this night - how unlike the wild effusion of two nights ago - how unlike what I should have written last night -" (461). "Last night" remains, however, a conspicuous lacuna of Shelley's journal as whatever was being considered on the night of 18 March is not recorded, the preceding entry being that of 17 March. In the pre-1822 journal, there are few isolated examples of the diarist's revising, or post-dating, entries of previous days, presumably on finding factual mistakes. This is demonstrated by corrections visible in fragments such as the following (1821):

Friday June 1st

Write - Greek - The W's eome - walk - S. goes to Pisa - Mr Taaffe calls Saturday 2nd

Write - Greek - S. goes to Pisa - Mr Taaffe ealls. walk to Pisa with W. Monday 4th 
Write. Greek - Walk to the W. - S. at Pisa - he does not return until midnight - a thunder storm

Teusday [sic] 5th

Write - Walk to the W. S. at Pisa he does not return until midnight - A rainy day - walk in the evening (369).

But then it is equally possible that the diarist is barely catching up with the events of a couple of days which she has missed, but her meticulous care to present the facts as they were, with no distortion, is visible. Needless to say, a large proportion of Shelley's entries, at all stages of her journalising, contain numerous minor alterations and/or improvements. These are usually limited to corrections of slips of the pen or substituting one word for another, but are not the effects of later editing, being introduced contemporaneously at the time of writing, as can be ascertained upon visual examination of the manuscript.

This results from a major distinctive feature of the Shelley's diaristic practice - the abundance of temporal gaps, the increasing duration and the decreasing frequency of the entries (no longer daily, weekly or, later, not even monthly) which becomes striking after the year 1822 . While gaps do occur in the pre-1822 journal as well, they tend to be rather short, covering spans of several days - from three to over a fortnight. Needless to say, dated blanks tend to occur in the pre-1822 journal exclusively.

As "a diary is not only a text: it is a behavior, a way of life, of which the text is merely a trace or by-product" (Lejeune 2009: 268), all the above illustrate an overwhelming need on the part of the diarist to assume, or re-assume - as need be, control over her life and actions, even if the only place where such control can be executed is her life writing. This drive towards the defining of her lacunae - even towards the elimination thereof, in Lejeunean terms, "kills" a journal by removing its, however tenuous, spontaneity and sincerity. Yet when a diarist, a control freak of sorts, attempts to achieve superior organisation of her material by imposing those self-referential frames which take the form of intertitles - to render her jottings clearer and less ambiguous even to herself - does it still make sense to speak of "killing" rather than breathing new life into an otherwise obscure text? I do not think so: the result is higher artistic - and personal - integrity. After all, as Genette tells us (1997: 294), "in contrast to general titles, which are addressed to the public as a whole and may have currency well beyond the circle of readers, internal titles are accessible to hardly anyone except readers, or at least the already limited public of browsers and readers of tables of contents; and a good many internal titles make sense only to an addressee who is already involved in reading the text, for these internal titles presume familiarity with everything that has preceded." And if the addressee and the reader are both identical with the journal writer, the problem of "killing" simply ceases to exist.

All this clearly adds to our understanding of Mary Shelley's diaristic oeuvre and shows her in the process of creatively experimenting with the constraints of the journal genre. Shelley's life writing, then, needs to be put in the limelight, as 
opposed to the critical practice of several past decades which focused primarily on her best-known novel, Frankenstein (1818), and - more recently - several others: Valperga (1823), The Last Man (1826), The Fortunes of Perkin Warbeck (1830), Lodore (1835) and Falkner (1837). This neglect of Shelley's life writing may be, as Judy Simons points out, due to the fact that "Mary Shelley's journal, like Dorothy Wordsworth's, is an example of a document which has been considered of value in the past because of its insights into the work of a male poet" (1990: 16) ${ }^{8}$ It is a pity that, in general handbooks of English romantic literature, Shelley's journals are hardly included. This is the case with The Bloomsbury Guide to Romantic Literature from 1790 to 1830 (Ward 1993: 221). Duncan Wu's 1995 Romanticism: A Critical Reader fails to include the journals at all, and offers instead a Frankenstein chapter by Margaret Homans. In a similar vein, Wu's 1999 Companion to Romanticism has a Frankenstein chapter by John Beer. Nicholas Roe's 2005 Romanticism: An Oxford Guide represents a relative breakthrough: in her article entitled "Letters, Journals and Diaries", Nichola Deane considers - though sketchily - Mary Shelley's journals (2005: 581-82). Against this background, a genuine highlight is provided somewhat earlier by Sheila Ahlbrand's essay "Author and Editor: Mary Shelley's Private Writings and the Author Function of Percy Bysshe Shelley" (1997). Ahlbrand's preoccupation is the Shelleys' joint authorship of the journals; Mary Shelley's activities as Percy Bysshe Shelley's editor, biographer and autobiographer; as well as the issues of her identity, self-representation and representation of her husband. Even the 2003 Cambridge Companion to Mary Shelley contains no chapter devoted to her journals.

\section{Notes}

$1 \quad$ This issue has been pondered by many scholars, including Arthur Ponsonby (1923), Wayne Shumaker (1954), Roy Pascal (1960), Robert Fothergill (1974), John Sturrock (1977), Jean Starobinski (1980), A. O. J. Cockshut (1984), Paul John Eakin (1985), Roman Zimand (1979; 1990), Leigh Gilmore (1995), Regina Lubas-Bartoszyńska (2003) and Philippe Lejeune (2009).

2 The five are extant; more may be missing. For a discussion of other aspects of Shelley's life writing, see Magdalena Ożarska (2013).

3 All quotations from the Shelley journals come from the following edition: Shelley, Mary. 1995. The Journals of Mary Shelley 1814-1844. Eds. Paula R. Feldman and Diana ScottKilvert. The Johns Hopkins University Press: Baltimore and London. Cf. Stanzel (1984: 37): "detailed chapter headings summarising the contents of chapters". "End[ing] with my happiness" may sound ambivalent at first glance: does the diarist mean to say that the book finishes on a happy note? Or, rather, that it does away with her happiness once and for all?

$6 \quad$ For an exhaustive discussion of the use of epigraphs in eighteenth- and nineteenth-century English fiction, as well as in Jean-Jacques Rousseau's Julie, or the New Heloise (1761), a text fundamental in shaping Mary Shelley's writerly imagination, see Genette (1997: 144-146). For a detailed discussion of Shelley's "Choice" as an elegy, see Graham Allen (2007). It is to Simons that we owe an apt classification of Shelley's journals into "three discrete stages, each with its own distinctive style": 1814-1815 - the early "concise but not secretive" 
stage; 1816-22 - the guarded and secretive stage; and the 1822-44 stage of emotional consolation, Shelley's journalising performing a therapeutic role (Simons 1990: 63-80). Importantly, Simons has also pointed out that "there is a direct relationship to be traced between Mary Shelley's published writings and her personal journal” (68).

\section{References}

Ahlbrand, Sheila (1997) Author and editor: Mary Shelley's private writings and the author function of Percy Bysshe Shelley. In: Syndy M. Conger, Frederick S. Frank and Gregory O'Dea. (eds.) Iconoclastic Departures: Mary Shelley after Frankenstein. Essays in Honor of the Bicentenary of Mary Shelley's Birth. Cranbury, NJ; London; Missisauga, Ontario: Associated University Presses, 35-61.

Allen, Graham (2008) Mary Shelley: Critical Issues. Houndmills, Basingstoke: Palgrave Macmillan.

Blodgett, Harriet (1988) Centuries of Female Days: English Women's Private Diaries. New Brunswick, NJ: Rutgers University Press.

Cockshut, A. O. J. (1984) The Art of Autobiography in 19th and 20th Century England. New Haven and London: Yale University Press.

Culley, Margo, ed. (1985) A Day at a Time: The Diary Literature of American Women from 1764 to the Present. New York: The Feminist Press at City University of New York.

Czermińska, Małgorzata (1977) Rola odbiorcy w dzienniku intymnym [The Role of the Addressee in Personal Journals]. In: Tadeusz Bujnicki and Janusz Sławiński (eds.) Problemy odbioru i odbiorcy [Problems of Reception and Addressees]. Wrocław, Warsaw, Krakow, Gdańsk: Zakład Narodowy im. Ossolińskich, 105-122.

Deane, Nichola (2005) Letters, journals and diaries. In: Nicholas Roe (ed.) Romanticism: An Oxford Guide. Oxford: Oxford University Press, 574-589.

Eakin, Paul John (1985) Fictions in Autobiography: Studies in the Art of Self-Invention. Princeton, New Jersey: Princeton University Press.

Feldman, Paula R. and Diana Scott-Kilvert (1995) Introduction. In: The Journals of Mary Shelley 1814-1844. Baltimore and London: The Johns Hopkins University Press, xv-xxiii.

Fothergill, Robert A. (1974) Private Chronicles: A Study of English Diaries. London, New York and Toronto: Oxford University Press.

Genette, Gérard (1980) Narrative Discourse. Trans. Jane E. Lewin. Oxford: Basil Blackwood.

Genette, Gérard (1997) Paratexts: Thresholds of Interpretation. Trans. Jane E. Lewin. Cambridge: Cambridge University Press.

Gilmore, Leigh (1995) Autobiographics: a Feminist Theory of Women's Self-Representation. New York: Cornell University Press.

Jackson, Anna (2010) Diary Poetics: Form and Style in Writers'Diaries, 1915-1962. New York and London: Routledge.

Lejeune, Philippe (2001) How do diaries end? Biography 24 (1), 99-112.

Lejeune, Philippe (2009) On Diary. Eds. Jeremy D. Popkin and Julie Rak. Transl. Katherine Durnin. Honolulu: University of Hawai'i Press.

Lubas-Bartoszyńska, Regina (2003) Pisanie autobiograficzne w kontekstach europejskich [Autobiographical Writing in European Contexts]. Katowice: Wydawnictwo Śląsk.

Ożarska, Magdalena (2013) Lacework or Mirror? Diary Poetics of Frances Burney, Dorothy Wordsworth and Mary Shelley. Newcastle-upon-Tyne: Cambridge Scholars Publishing.

Pascal, Roy (1960) Design and Truth in Autobiography. Cambridge, Massachusetts: Harvard University Press.

Ponsonby, Arthur (1923) English Diaries: A Review of English Diaries from the $16^{\text {th }}$ to the $20^{\text {th }}$ Century with an Introduction on Diary Writing. London: Methuen. 
Rak, Julie (2009) Dialogue with the future: Philippe Lejeune's method and theory of diary. In: Philippe Lejeune. On Diary. Jeremy D. Popkin and Julie Rak (eds.), Katherine Durnin (transl.). Honolulu: University of Hawai'i Press, 16-26.

Roe, Nicholas, ed. (2005) Romanticism: An Oxford Guide. Oxford: Oxford University Press.

Shelley, Mary (1995) The Journals of Mary Shelley 1814-1844. Eds. Paula R. Feldman and Diana Scott-Kilvert. Baltimore and London: The Johns Hopkins University Press.

Shumaker, Wayne (1954) English Autobiography: Its Emergence, Materials and Form. Berkeley and Los Angeles: University of California Press.

Simons, Judy (1990) Dark imagery: The journal of Mary Shelley. In: Diaries and Journals of Literary Women from Fanny Burney to Virginia Woolf. London: Macmillan, 61-82.

Smith, Sidonie, and Julia Watson (2001) Reading Autobiography: A Guide for Interpreting Life Narratives. Minneapolis and London: University of Minnesota Press.

Spalding, Philip Anthony (1949) Self-Harvest; a Study of Diaries and the Diarist. London: Independent Press.

Stanzel, F. K. (1984) A Theory of Narrative. Cambridge: Cambridge University Press.

Starobinski, Jean (1980) The style of autobiography. Autobiography: Essays Theoretical and Critical. Ed. James Olney. Princeton, New Jersey: Princeton University Press. 73-83.

Sturrock, John (1977) The new model autobiographer. New Literary History, 9 (1), 51-63.

Sweet, Rosemary (2009) Cities of the Grand Tour: Changing Perceptions of Italian Cities in the Long Eighteenth Century. http://www.grandtour.amdigital.co.uk/Essays/Content/rosemarysweet. aspx. Accessed on June 2, 2016.

Ward, Geoff, ed. (1993) Romantic Literature from 1790 to 1830. London: Bloomsbury.

Wu, Duncan, ed. (1995) Romanticism: A Critical Reader. London: Blackwell Publishers.

Zimand, Roman (1990) Diarysta Stefan Ż. [Diarist Stefan Ż.]. Wrocław, Warszawa, Kraków: Wydawnictwo PAN.

Zimand, Roman (1979) 'W nocy od 12 do 5 rano nie spatem': dziennik Adama Czerniakowa próba lektury ['This night, I haven't slept between 12 and 5 a.m.': Adam Czerniaków's Journal - a Reading]. Paris: Libella.

Magdalena OżarsKa, Ph.D. habil. is Associate Professor at Jan Kochanowski University in Kielce, Poland. She is the author of Meanderings of the English Enlightenment: The Literary Oeuvre of Christopher Smart (2008), Lacework or Mirror? Diary Poetics of Frances Burney, Dorothy Wordsworth and Mary Shelley (2013) and Two Women Writers and their Italian Tours: Mary Shelley's "Rambles in Germany and Italy in 1840, 1842 and 1843" and Lucja Rautenstrauchowa's "In and Beyond the Alps" (2014). Her research interests include $18^{\text {th }}$ - and $19^{\text {th }}$-century English and Polish women's self writing, animal studies, critical plant studies and food studies.

Address: Magdalena Ożarska, Ph.D. habil., Assoc. Prof., Department of Modern Languages, Jan Kochanowski University, ul. Świętokrzyska 21D, 25-406 Kielce, Poland. [email: mozarska@gmail. com] 
